\title{
Effect of herbicides on weed control efficiency (WCE) and yield attributes in brinjal (Solanum melongena $\mathbf{L}$.)
}

\author{
Mr. Shivalingappa S. Bangi ${ }^{1}$, Dr. Eugenia P. Lal ${ }^{2}$, \\ Mr. Santosh S.Bangi ${ }^{3}$, Mr.Umesh T. Sattigeri ${ }^{4}$ \\ ${ }^{1}$ (Dept. of Biological Sciences, Sam Higginbottom Institute of Agriculture, Technology and Sciences, India) \\ ${ }^{2}$ (Dept. of Biological Sciences, Sam Higginbottom Institute of Agriculture, Technology and Sciences, India) \\ ${ }^{3}$ (University of Horticultural Sciences, Bagalkot,India) \\ ${ }^{4}$ (Dept. of Biological Sciences, Sam Higginbottom Institute of Agriculture, Technology and Sciences, India)
}

\begin{abstract}
A field experiment was conducted during Rabi season of 2014 to study the effect of herbicides on weed control efficiency and yield attributes in Brinjal. The experiment consisting of 10 treatments comprising 4 herbicides (alachlor at 1.0 and $1.5 \mathrm{~kg}$ a.i. /ha, butachlor at 1.0 and $1.5 \mathrm{~kg}$ a.i. /ha, pendimethalin at 1.0 and 1.5 $\mathrm{kg}$ a.i. /ha, pretilachlor at 1.0 and $1.5 \mathrm{~kg}$ a.i. /ha) compared with weed free check, unweeded control. Results revealed that the application of butachlor and pretilachlor at $1.5 \mathrm{~kg}$ a.i. Tha were found to be phytotoxic while pendimethalin at 1.0 and $1.5 \mathrm{~kg}$ a.i. Tha was found not phytotoxic to the brinjal. The total number and total dry weight of weeds were found to be maximum in unweeded control and weed control treatments decreased these parameters but pendimethalin at $1.5 \mathrm{~kg}$ a.i. /ha were the lowest. WCE (\%) was highest with the pendimethalin at $1.5 \mathrm{~kg}$ a.i. Tha. The yield parameters viz., number of fruits, fruit weight, and fruit yield decreased significantly in unweeded control while weed index was higher. The fruit yield was significantly higher with application of pendimethalin at $1.5 \mathrm{~kg}$ a.i. /ha.
\end{abstract}

Keywords: Herbicide, Leaf area, Solanum melongena, WCE, Yield.

\section{Introduction}

Brinjal (Solanum melongena L.) is an important commercial vegetable crop. It belongs to the family solanaceae. Brinjal is also variously known as Egg plant or Aubergine (French name) or Guineasfaush. It is one of the most common, popular and principal vegetable crops grown in India and other parts of world. It is also popular in France, Italy and United states. India is regarded as the centre of origin of brinjal crop (Vavilov, 1931; Bhaduri, 1951).

Weeds pose most serious problem in brinjal cultivation because of liberal use of farmyard manure, chemical fertilizers and frequent irrigations that help the weeds to grow vigorously. It has been well established that losses from weeds accounts for 45 per cent more than when compared to insect, pest and diseases about 30 and 20 per cent, respectively (Rao, 1993). In most of the vegetables crops, the early growth period is the most critical stage at which stresses of any kind affects the economic yields. Weed competition is one such important stress during this period. Besides, this period coincides with the season of peak labour activity leading to scarcity of labour for weeding. This adds to the already high costs of production. So proper weed control method, therefore, is the prime need and very much essential to give herbicide usage its share to obtain maximum productivity.

The herbicides when used in combination with one or two hand weedings, improves their efficiency and the pre-emergent herbicides are beneficial to keep the crop weed free in the early stages. During later stages, hand weeding helps to reduce the cost of weeding and keep the weed population below the economic threshold level throughout the crop growth period. Keeping all this in view, the present study was carried out the effect of herbicides on weed control efficiency, and yield attributes in brinjal.

\section{Materials And Methods}

The present experiment was conducted in research field at Department of Biological Sciences, Sam Higginbottom Institute Agriculture, Technology and Sciences, Allahabad, (U.P.) in the Rabi season of 2014 on brinjal (Solanum melongena L.) verity Manjula.

This experiment was laid out in Randomized block design. The treatments were involving four different herbicides with two different rates of application (1.0 and $1.5 \mathrm{~kg}$ active ingredient per hector) were applied as pre-emergent herbicide and having one inter cultivation after 30 days of transplanting.. The details of all the treatments are furnished below.

$\mathrm{T}_{1}$ : Alachlor (50\% EC) @ $1.0 \mathrm{~kg}$ a.i. ha- ${ }^{1}+1 \mathrm{IC}$ at $30 \mathrm{DAT}$

$\mathrm{T}_{2}$ : Alachlor (50\% EC) @ $1.5 \mathrm{~kg}$ a.i. $\mathrm{ha}^{-1}+1 \mathrm{IC}$ at $30 \mathrm{DAT}$ 
$\mathrm{T}_{3}$ : Butachlor (50\% EC) @ $1.0 \mathrm{~kg}$ a.i. $\mathrm{ha}^{-1}+1 \mathrm{IC}$ at $30 \mathrm{DAT}$

$\mathrm{T}_{4}$ : Butachlor (50\% EC) @ $1.5 \mathrm{~kg}$ a.i. ha ${ }^{-1}+1 \mathrm{IC}$ at $30 \mathrm{DAT}$

$\mathrm{T}_{5}$ : Pendimethalin (30\% EC) @ $1.0 \mathrm{~kg}$ a.i. $\mathrm{ha}^{-1}+1 \mathrm{IC}$ at $30 \mathrm{DAT}$

$\mathrm{T}_{6}$ : Pendimethalin (30\% EC) @ $1.5 \mathrm{~kg}$ a.i. $\mathrm{ha}^{-1}+1 \mathrm{IC}$ at $30 \mathrm{DAT}$

$\mathrm{T}_{7}$ : Pretilachlor (45\% EC) @ $1.0 \mathrm{~kg}$ a.i. $\mathrm{ha}^{-1}+1 \mathrm{IC}$ at $30 \mathrm{DAT}$

$\mathrm{T}_{8}$ : Pretilachlor (45\% EC) @ $1.5 \mathrm{~kg}$ a.i. $\mathrm{ha}^{-1}+1 \mathrm{IC}$ at $30 \mathrm{DAT}$

$\mathrm{T}_{9}$ : Weed free check $+1 \mathrm{IC}$ at $30 \mathrm{DAT}$

$\mathrm{T}_{10}$ : Unweeded control

* EC: Emulsifiable concentrate.

* IC: Intercultivation

*a.i. Active ingredient

\subsection{Observations On Weed Parameters}

\subsubsection{Weed population count}

The total number of weeds present in $0.25 \mathrm{~m}^{2}$ area in a permanently marked sampling area was counted at 30,60, 90, 120 DAT in each treatment.

\subsubsection{Dry weight of weeds $\left(\mathrm{g} / 0.25 \mathrm{~m}^{2}\right)$}

Dry weight of weeds was recorded at periodical intervals i.e., 30, 60, 90, 120 DAT in each treatment. The weeds were uprooted from the $0.25 \mathrm{~m}^{2}$ area selected at random each time and were oven dried to a constant weight at $65^{\circ} \mathrm{C}$ and the oven dry weight of weeds was recorded. The dry weight of weeds was expressed as g per $0.25 \mathrm{~m}^{2}$.

\subsubsection{Weed control efficiency $(\%)$}

Weed control efficiency (WCE) denotes the magnitude of weed reduction due to weed control treatment. It was worked out by using the formula suggested by Mani $\boldsymbol{e t}$ al. (1973) and expressed in percentage. WUE $(\%)=\frac{\text { Dry weight of weeds in unweeded control-dry weight of treatment plot }}{\text { Dry weight of weeds in unweeded control }} \times 100$

\subsubsection{Weed index $(\%)$}

Weed index is defined as the magnitude yield reduction due to presence of weeds in comparison with weed free check. In other words weed index expresses the competition offered by weeds measured by per cent reduction in yield owing to their presence in the field (Gill and Vijayakumar, 1969). Weed index was calculated by using following formulae. Weed index $(\%)=\frac{X-Y}{x} \times 100$ Where, $\mathrm{x}=$ Total yield from the weed free check

$\mathrm{y}=$ Total yield from the treatment for which weed index has to be calculated.

\subsection{Morphological Parameters}

\subsubsection{Plant height $(\mathrm{cm})$}

The plant height was measured from the base of the plant to the terminal growing point of the main stem at 30,60, 90, 120 DAT. The average plant height was worked out and expressed in centimeters.

\subsubsection{Number of leaves per plant}

The number of leaves per plant were measured at 30,60, 90, 120 DAT for three rows plants and then mean was worked out.

\subsubsection{Number of branches per plant}

The number of branches per plant at 30,60,90,120 DAT were counted for three rows plants and then mean was calculated.

\subsection{Biochemical Parameters}

\subsubsection{Chlorophyll content}

The chlorophyll content was measured by following the method of Arnon (1949). A known weight of $250 \mathrm{mg}$ of fresh leaves were cut into small pieces and homogenized with $10 \mathrm{ml}$ of $80 \%$ acetone in a mortar with pestle. leaf extracts is then transferred to a centrifuge tube and centrifuged at $3000 \mathrm{rpm}$ for 10 minutes. After a centrifugation, the supernatant is transferred to a $25 \mathrm{ml}$ volumetric flask and the volume is made up to $25 \mathrm{ml}$ using the same $80 \%$ acetone. The value is measured at 645 and $663 \mathrm{~nm}$. The total chlorophyll content were calculated at $30,60,90,120$ DAT by using the following formula.

Chlorophyll a : $\{12.7$ x $663-2.69$ x 645 x V $\} /(1000$ x W $) \mathrm{mg} / \mathrm{g}$ 
Chlorophyll b : $\{22.7$ x645 - $4.08 \times 663$ x V $\} /(1000 \times$ W $) \mathrm{mg} / \mathrm{g}$

Where, $\mathrm{V}=$ volume of aliquot finally made up using $80 \%$ acetone

$\mathrm{W}=$ Weight of material taken in $\mathrm{g}$.

\subsubsection{Nitrate reductase activity}

The nitrate reductase activity (NRA) in vivo was estimated by following the method of Saradhambal et al. (1978). Leaves were cut into small round discs, and their fresh weight was determined. These discs were floated in petridish having $0.1 \mathrm{M} \mathrm{KNO}_{3}$ under bright light for one hr for complete stomatal opening. The discs were transferred to $25 \mathrm{ml}$ flasks containing $5.0 \mathrm{ml}$ of solution having $0.1 \mathrm{M}$ phosphate buffer $(\mathrm{pH} 7.5), 0.02 \mathrm{M}$ $\mathrm{KNO}_{3}$, propanol $(5 \%)$ and two drops of chloromphenicol $(0.5 \mathrm{mg} / \mathrm{ml})$ and incubated at $30^{\circ} \mathrm{C}$ for 30 minutes in dark. The reaction was stopped by adding $0.1 \mathrm{ml}$ of zinc acetate $(1.0 \mathrm{M})$ and $1.0 \mathrm{ml}$ of ethanol $(70 \%)$. The contents were centrifuged at $3000 \mathrm{rpm}$ for 10 minutes and the supernatant was collected. To which, $1.0 \mathrm{ml}$ of sulphanilamide (1\%) and $1.0 \mathrm{ml}$ of NNEDA (0.02\%) were added and incubated at room temperature for 20 minutes. The total volume in the test tubes was $9.0 \mathrm{ml}$. The absorbance of pink colour developed at the end of incubation was measured at $540 \mathrm{~nm}$ in spectrophotometer. The activity of nitrate reductase was expressed as $\mathrm{n}$ mol $\mathrm{NO}_{2}$ formed per $\mathrm{g}$ fresh weight per hour.

\subsection{Yield and yield components}

Various yield and yield components were estimated from the three rows plants used for recording morphological parameters and presented in table 2.

\subsubsection{Total number of fruits}

The total numbers of fruits from three tagged plants were counted in all the pickings and the average total numbers of fruits plant $^{1}{ }^{1}$ for the each treatment was worked out.

\subsubsection{Fruit weight (g /fruit)}

Five numbers of fruits from each treatment was weighed and they were worked out for single fruit weight and expressed in grams.

\subsubsection{Fruit yield (t/ha)}

The fresh fruit yield from the net plot area was taken to calculate the fruit yield per hectare.

\subsubsection{Statistical analysis and interpretation of data}

The data on various parameters were subjected to Fischer's method of analysis of variance and interpretation of data was done as described by Gomez and Gomez (1984). The level of significance used in ' $F$ ' and ' $t$ ' test was 0.05. Critical difference (CD) values were calculated whenever the F-test was significant.

\section{Results And Discussion}

\subsection{Observations On Weed Parameters}

\subsubsection{Weed population count}

The total number of weeds was highest in $\mathrm{T}_{10}$ (14.33) (20.67), (25.33), (30.67) followed by $\mathrm{T}_{7}(9.00)$, (11.33), (15.00), (20.00) While, significantly lowest total number of weeds were found in $\mathrm{T}_{6}(4.67)$, (6.33), (10.33), (13.33) at 30, 60, 90, 120 DAT respectively. Similar results were also obtained by Pandey et al. (1992) in onion.

\subsubsection{Total dry weight of weeds $\left(\mathrm{g} / 0.25 \mathrm{~m}^{2}\right)$}

The total dry matter accumulation of weeds was significantly higher in $\mathrm{T}_{10}$ (8.55), (11.42), (14.53), (15.50) and the lowest total dry weight of weeds was observed with weed $\mathrm{T}_{10}(0.00)$ followed by $\mathrm{T}_{6}(1.61)$, (2.22), (3.19) (4.31) these data were recorded after 30, 60, 90, 120 DAT respectively. The lower weed dry weight in weed control treatments may be ascribed to the less number of weeds, rapid depletion of carbohydrate reserves of weeds through rapid respiration (Dakshinadas, 1962) and may be due to reduced photosynthetic activity (Hilli and Santkemann, 1969).

\subsubsection{Weed control efficiency (WCE \%)}

Among the different herbicide treatments of weed control efficiency was found significantly higher $\mathrm{T}_{6}$ (81.16), (80.56), (78.04), and the lowest WCE was observed in $T_{7}$ (65.89), (61.90), (60.15), (51.34). These data were calculate after 30, 60, 90, 120 DAT respectively. Similar results have been obtained by Nadagouda (1995) and Nekar (1997). 


\subsection{Morphological Parameters}

\subsubsection{Plant height $(\mathbf{c m})$}

The $\mathrm{T}_{9}$ recorded significantly the highest plant height (17.97), (47.13), (75.0), (87.20) followed by $\mathrm{T}_{6}$ (16.77), (45.80), (73.20), (86.27) and amoung the herbicides the lowest plant height was recorded in $\mathrm{T}_{7}(14.36)$, (40.03), (66.83), (76.63) these data were found after 30, 60, 90, 120 DAT respectively. The crop was adversely affected by weeds in unweeded control due to heavy competition with crop for nutrients, moisture, space and light, which can be attributed for suppressed crop growth. Similar results were also noticed by Manjunath $\boldsymbol{e t}$ al. (1989) and Singh and Singh (1994) in onion.

\subsubsection{Number of leaves per plant}

Among the herbicide treatments the number of leaves were significantly higher in $\mathrm{T}_{6}$ (20.33), (78.33), (134.67), (170.0) Whereas, $T_{7}$ was recorded lowest number of leaves (15.33), (70.0), (106.67), (130.67) these data were found $30,60,90,120$ DAT respectively. These results are in agreement with the findings of Manjunath et al. (1989) and Singh and Singh (1994) in onion.

\subsubsection{The number of branches}

In different herbicide treatment the $\mathrm{T}_{6}$ was recorded the highest number of branches (5.33), (14.67), (23.33), (24.67) and the treatment $\mathrm{T}_{7}$ recorded lower number of branches (3.33), (11.67), (14.33), (15.33) at 30, 60, 90, 120 DAT respectively. These results are in conformity with the findings of Ajaykumar and Thakral (1993) in chilli.

\subsection{Biochemical Parameters}

\subsubsection{Chlorophyll content}

Among the different herbicide treatments the $\mathrm{T}_{6}$ was recorded highest total chlorophyll content (1.24), (1.97), (1.70), (1.49) Whereas, lowest total chlorophyll content was recorded in $T_{7}(1.10),(1.84),(1.64),(1.40)$ these were recorded 30, 60, 90, 120 DAT respectively. Similar results were also noticed by Channappagowda et al. (2007).

\subsubsection{Nitrate reductase activity}

Among the different herbicide treatments $\mathrm{T}_{6}$ registered significantly higher NRA values (38.40), (98.63), (78.67), (34.97) and the treatment $\mathrm{T}_{7}$ recorded significantly lower NRA value (35.07), (95.03), (75.23), (32.90) at 30,60, 90, 120 DAT respectively. These results are in agreement with the findings of

\section{Channappagoudar et al. (2013).}

\subsection{Yield and yield components}

\subsubsection{Number of fruits per plant}

The data on number of fruits per plant indicated significant differences due to influence of herbicide treatments and crop weed competition and the data presented in Table 2. The number of fruits per plant significantly higher in $\mathrm{T}_{9}$ (26.67) followed by $\mathrm{T}_{6}(25.67), \mathrm{T}_{5}$ (24.67). However, the lowest number of fruits recorded in $\mathrm{T}_{10}$ (16.67) followed by $\mathrm{T}_{7}(17.33)$.

\subsubsection{Fruit weight (g/fruit)}

The data on fruit weight per fruit presented in Table 2 was influenced by different herbicide treatments and crop weed competition. The fruit weight is significantly higher in treatment $\mathrm{T}_{9}$ (71.43) and $\mathrm{T}_{6}(71.30)$. However, lowest fruit weight per fruit was observed in treatment $\mathrm{T}_{10}(66.33)$ followed by $\mathrm{T}_{7}(66.63)$.

\subsubsection{Yield (t /ha)}

The data on brinjal yield indicated significant differences due to herbicide treatments and crop weed competition and data presented in Table 2 . The yield was obtained significantly higher in $\mathrm{T}_{9}(42.31)$ followed by $\mathrm{T}_{6}$ (40.67), $\mathrm{T}_{5}$ (38.75). However, the lowest yield was recorded in $\mathrm{T}_{10}$ (24.44) followed by $\mathrm{T}_{7}$ (25.64). These results are in agreement with the findings of Frost and Hingston (2004) in chilli.

\subsubsection{Weed index (\%).}

The lowest weed index values were found in $\mathrm{T}_{9}(0.00)$ followed by $\mathrm{T}_{6}(4.24), \mathrm{T}_{5}(8.44)$. However, $\mathrm{T}_{10}$ treatment recorded highest weed index (53.13) followed by $\mathrm{T}_{7}(3$ 


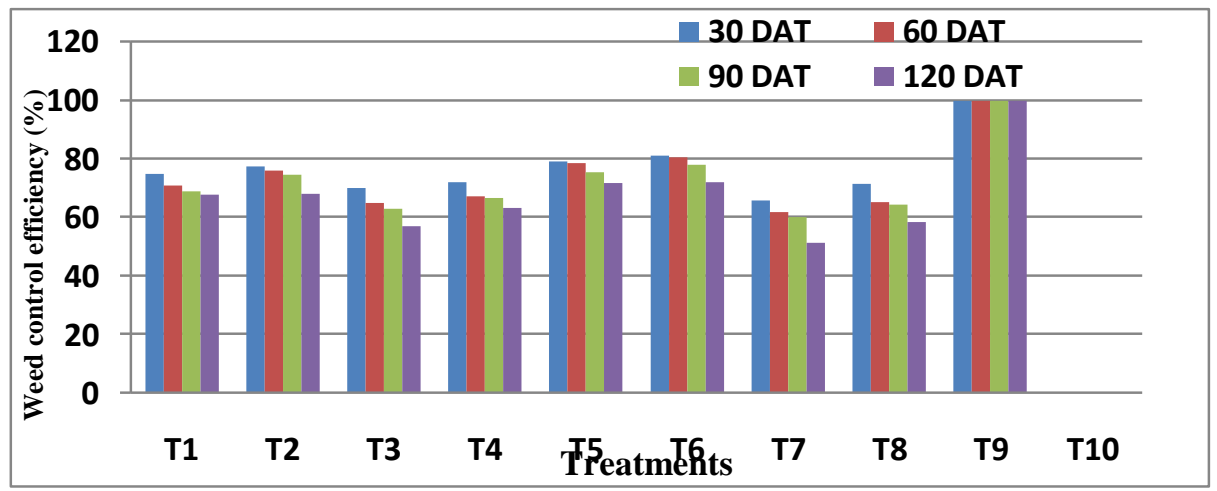

Fig.3.1.3 Effect of herbicides and crop weed competition on weed control efficiency (\%) at different stages in brinjal.

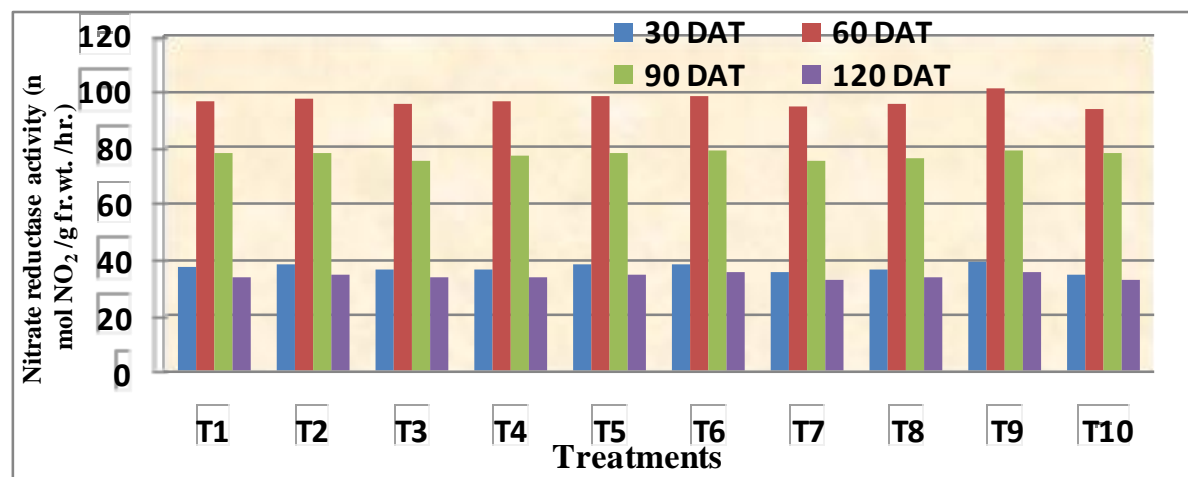

Fig. 3.3.2 Effect of herbicides and crop weed competition on nitrate reductase activity (n mol $\quad \mathrm{NO}_{2} / \mathrm{g}$ fr.wt /hr.) at different stages in brinjal.

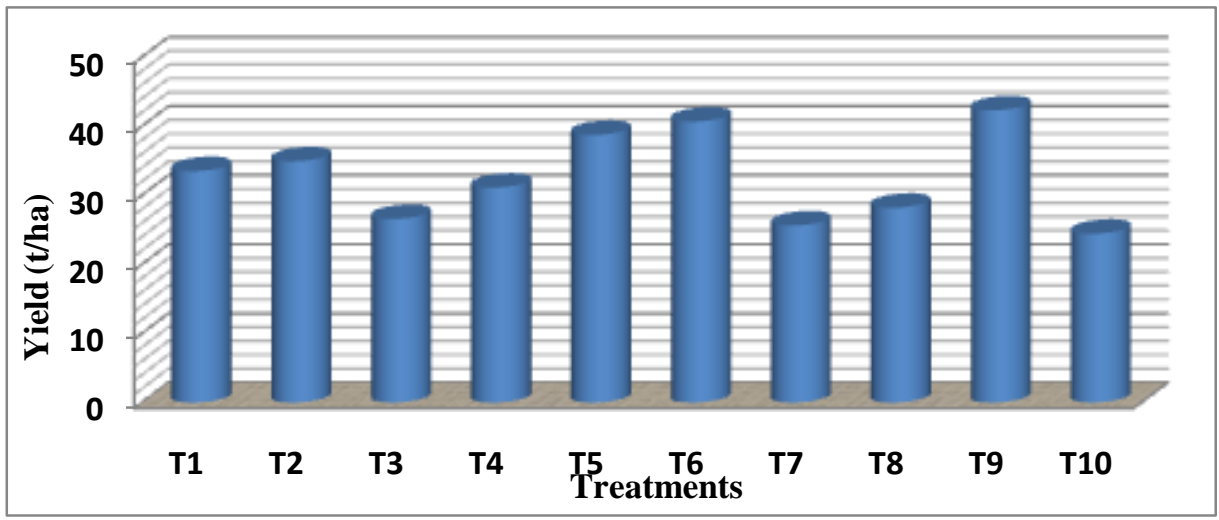

Fig. 3.4.3 Effect of herbicides and crop weed competition on yield $(\mathrm{t} / \mathrm{ha})$. 
Effect of herbicides on weed control efficiency (WCE) and yield attributes in brinjal .....

Table: 1 Effect of herbicides and crop weed competition at different stages in brinjal.

\begin{tabular}{|c|c|c|c|c|c|c|c|c|c|c|c|c|c|c|c|c|}
\hline Treatments & 30DAT & $60 \mathrm{DAT}$ & $90 \mathrm{DAT}$ & 120DAT & $30 \mathrm{DAT}$ & $60 \mathrm{DAT}$ & $90 \mathrm{DAT}$ & $120 \mathrm{DAT}$ & $30 \mathrm{DAT}$ & $60 \mathrm{DAT}$ & $90 \mathrm{DAT}$ & 120DAT & $30 \mathrm{DAT}$ & $60 \mathrm{DAT}$ & $90 \mathrm{DAT}$ & 120DAT \\
\hline $\mathrm{T}_{1}$ & 7.33 & 9.33 & 13.67 & 17.00 & 2.14 & 3.34 & 3.80 & 5.01 & 1.18 & 1.90 & 1.67 & 1.45 & 15.85 & 42.57 & 70.43 & 83.23 \\
\hline $\mathrm{T}_{2}$ & 6.33 & 8.33 & 12.33 & 16.00 & 1.93 & 2.73 & 3.68 & 4.96 & 1.19 & 1.92 & 1.67 & 1.46 & 16.43 & 44.07 & 71.77 & 84.53 \\
\hline $\mathrm{T}_{5}$ & 6.33 & 7.33 & 12.00 & 14.67 & 1.78 & 2.45 & 3.55 & 4.38 & 1.21 & 1.94 & 1.69 & 1.48 & 16.50 & 44.77 & 72.97 & 85.67 \\
\hline $\mathrm{T}_{6}$ & 4.67 & 6.33 & 10.33 & 13.33 & 1.61 & 2.22 & 3.19 & 4.31 & 1.24 & 1.97 & 1.70 & 1.49 & 16.77 & 45.80 & 73.20 & 86.27 \\
\hline $\mathrm{T}_{7}$ & 9.00 & 11.33 & 15.00 & 20.00 & 2.92 & 4.35 & 5.79 & 7.54 & 1.10 & 1.84 & 1.64 & 1.40 & 14.36 & 40.03 & 66.83 & 76.63 \\
\hline$T_{8}$ & 7.67 & 9.00 & 14.00 & 18.00 & 2.44 & 3.97 & 5.19 & 6.46 & 1.13 & 1.88 & 1.66 & 1.43 & 15.03 & 41.43 & 67.63 & 78.63 \\
\hline SEM & 0.49 & 055 & 0.68 & 0.92 & 0.39 & 0.19 & 0.19 & 0.23 & 0.01 & 0.01 & 0.00 & 0.01 & 0.38 & 0.80 & 0.57 & 0.55 \\
\hline $\mathrm{CD}(5 \%)$ & 1.46 & 1.63 & 2.01 & 2.75 & 1.15 & 0.56 & 0.57 & 0.68 & 0.03 & 0.04 & 0.01 & 0.02 & 1.13 & 2.37 & 1.68 & 1.65 \\
\hline
\end{tabular}

Table: 2 Effect of herbicides and crop weed competition at different stages and yield attributes in brinjal.

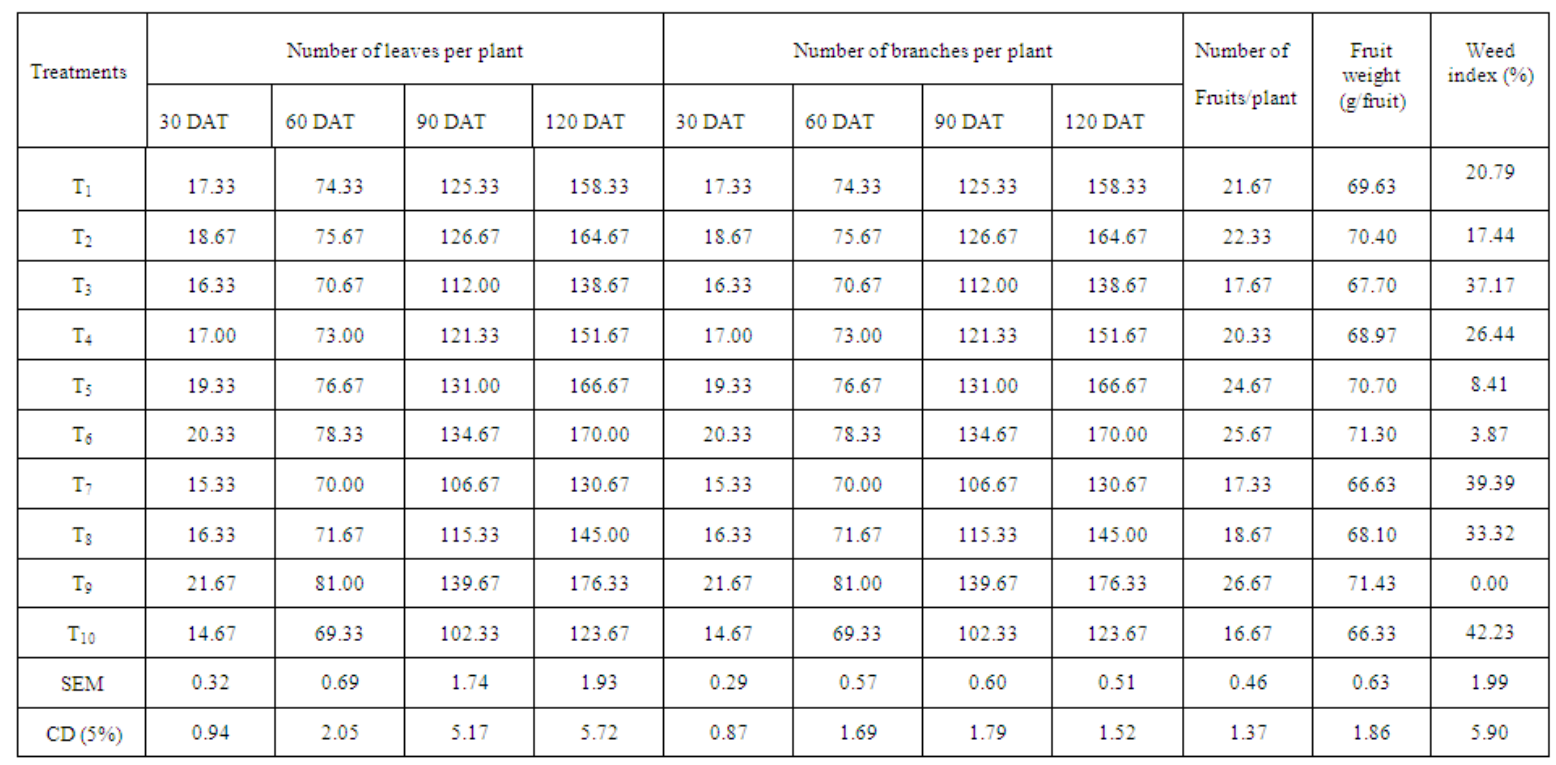

\section{Conclusion}

The present study revealed that pendimethalin@1.5 kg a.i. ha- ${ }^{1}$ have more significant among treatments which results less number of weeds, less dry weight (g), high weed control efficiency (WCE \%), and increased in morphological, biochemical parameters, yield attributes while comparing with all the treatments at 30, 60, 90, 120 DAT followed by pendimethalin @ $1.0 \mathrm{~kg}$ a.i. ha- ${ }^{1}$.

\section{Acknowledgements}

I great thankful to my parents Sadashiv M. Bangi, Suvarna S. Bangi and my whole family members. I spatial thanks to Ashwini S. Bangi, and my brother Santosh S.Bangi for their guidance, inspiring, co-operation, encouragement during the preparation of this manuscript.

\section{References}

[1]. Gill, G.S. and Vijayakumar 1969, "Weed index” A new method for reporting weed control trials. Indian J. Agron., 16,1969,96-98.

[2]. Saradhambal, K.V., Singh, S.P., Prakash, S. and Naik M.S., Effect of bacterial blight on the activities of nitrate reductase and peroxidase in rice plants. Indian J. Of Biochem Biophysics, 15,1978,105-107.

[3]. Pandey, R.P., Shukla, N. and Tiwari, J.P., Efficacy of herbicidal weed control in onion Indian J. Weed Sci., 22,1992, 34-37.

[4]. Dakshinadas, D.S.,Mode of action of plant growth regulator type weedicides Indian J. Agron., 6, 1962, 233-244.

[5]. Manjunath, S., Panchal, Y.C., Chimmad, V.P. and Koti, R.V., Studies on growth, $\quad$ yield and yield components of onion as influenced by herbicides and weeds. J. Maharashtra Agric Univ., 14, 1989, 200-203. 
[6]. Singh, M.P. and Singh, K.P.,Effect of crop-weed competition on growth and yield of kharif onion. Indian J. Weed Sci., 26, 1994,1821.

[7]. Rao, V.S.,Principles of Weed Sciences, Oxford and IBH publishing Co. New Delhi, 1993, pp.23-42.

[8]. Mani, V.S., Malla, M.L., Gautam, K.C. and Bhagwndas., Weed killing chemicals in potato cultivation. Indian Farm., VXXII, 1973, 17-18.

[9]. Hilli, L.V. and Santlemann, P.V.,Comparative effect of annual weeds on Spanish peanut. Weed Sci., 17, $1969,1-2$.

[10]. Nadagouda, B.T., Integrated weed management in drill sown onion (Allium Cepa L.). M.Sc. (Agri.) Thesis, Univ. Agric. Sci., Dharwad, Karnataka (India), 1995.

[11]. Nekar, M., Integrated weed management in garlic (Allium Cepa L.) in Northern transition tract of Karnataka. M. Sc. (Agri.) Thesis, Univ. Agric. Sci., Dharwad, Karnataka (India), 1997.

[12]. Ajaykumar and Thakral, K., Effect of herbicides and nitrogen fertilization on growth and yield of chilli (Capsicum annuum) In : Proc. Int. Symp. On Integrated Weed Management for Sustainable Agriculture, Hisar, India. Vol. III, 1993, $206-208$.

[13]. Frost, P.R. and Hingston, T.L., Evaluation of new herbicides for use in capsicum and chilli. Weed management : Balancing people, planet, profit, 14th Australian Weed Conf., Wagga, New South Wales, Australia 6 